International Business and Global Economy 2017, no. 36, pp. 114-127

Biznes międzynarodowy w gospodarce globalnej 2017, nr 36, s. 114-127

Edited by the Institute of International Business, University of Gdańsk

ISSN 2300-6102

e-ISSN 2353-9496

DOI 10.4467/23539496IB.17.008.7456

Tomasz Białowąs

Uniwersytet Marii Curie-Skłodowskiej w Lublinie

\title{
Główne czynniki spadku dynamiki handlu międzynarodowego w latach 2008-2015
}

Przedmiotem artykułu jest ocena wpływu głównych czynników na wartość i dynamikę handlu międzynarodowego w latach 2008-2015. W opracowaniu wskazano najważniejsze czynniki załamania handlu międzynarodowego w roku 2009 oraz jego stagnacji w latach 2012-2015. Wyniki przeprowadzonej analizy pozwalają stwierdzić, że zasadniczym czynnikiem spadku eksportu w roku $2009 \mathrm{i}$ w latach 2012-2015 było spowolnienie gospodarcze, a zwłaszcza załamanie inwestycji. Istotną rolę $\mathrm{w}$ spowolnieniu wymiany odegrało ponadto osłabienie powiązań $\mathrm{w}$ ramach globalnych łańcuchów wartości. Zmiany w polityce handlowej nie wywarly istotnego wpływu na załamanie handlu w roku 2009 i jego stagnację w latach 2012-2015. Dla lat 2012-2015 wykazano istotny wpływ spadku cen eksportowych na wartość światowego handlu, który w ujęciu wolumenowym rozwija się $w$ tempie zbliżonym do globalnego PKB, jednak w ujęciu wartościowym tempo wzrostu obrotów jest znacznie niższe.

Słowa kluczowe: handel międzynarodowy, polityka handlowa, wzrost gospodarczy

Klasyfikacja JEL: F40, F62, G01

\section{Main factors of the 2008-2015 slowdown in international trade}

The aim of the paper is to evaluate the main factors influencing the value and dynamics of international trade flows in 2008-2015. The author points to the main factors of the 2009 trade breakdown and 2012-2015 slowdown. Empirical analysis suggests the decline in exports can be largely traced to weaker economic activity, most notably subdued investment growth. The apparent decline in the growth of global value chains also played an important part in the observed slowdown. A small role was also played by the changes in trade policy. For 2012-2015, analysis reveals a significant impact of the decrease in export prices on global trade value, which has been growing at a similar rate as world GDP in volume terms, whereas in value terms the growth rate is much lower.

Keywords: international trade, trade policy, economic growth

JEL classification: F40, F62, G01 


\section{Wprowadzenie}

Największy spadek dynamiki handlu międzynarodowego w całym okresie po II wojnie światowej rozpoczął się w drugim kwartale 2008 r. Po ożywieniu trwającym od II kwartału 2009 r. do III kwartału 2011 r. nastąpił okres niskiej dynamiki wzrostu obrotów w handlu międzynarodowym. Tempo wzrostu obrotów handlowych pozostawało niższe niż wzrost światowego PKB, a otwartość handlowa spadła.

O ile czynniki załamania wymiany handlowej w roku 2009 są relatywnie dobrze poznane i wyjaśnione, o tyle przyczyny stagnacji w latach 2012-2015 pozostają przedmiotem ożywionej dyskusji akademickiej. Wśród najczęściej wymienianych powodów spowolnienia handlu międzynarodowego wymienia się: sekularną stagnację, spadek dochodowej elastyczności eksportu, nasilenie tendencji protekcjonistycznych oraz spadek cen eksportowych.

Celem artykułu jest wskazanie głównych czynników załamania handlu międzynarodowego w roku 2009 oraz jego stagnacji w latach 2012-2015. Szczegółową analizą objęto trzy obszary badawcze:

- zjawisko sekularnej stagnacji i obniżenie aktywności inwestycyjnej,

- spadek dochodowej elastyczności eksportu w rezultacie zmniejszenia skali fragmentaryzacji produkcji,

- wzrost protekcjonizmu pozataryfowego i spowolnienie procesu liberalizacji handlu,

- spadek cen eksportowych i zmniejszenie wartości światowego handlu.

\section{Główne tendencje w rozwoju handlu międzynarodowego w latach 2008-2015}

Etap największego spadku dynamiki handlu międzynarodowego w całym okresie po II wojnie światowej rozpoczął się w II kwartale 2008 r. (tab. 1). Światowy eksport w I kwartale 2009 r. zmniejszył się o $22 \%$ w stosunku do IV kwartału 2008 r. i o 31\% w relacji do I kwartału 2008 r. [WTO, 2017].

Załamanie obrotów handlowych dotyczyło praktycznie wszystkich krajów świata bez względu na poziom ich rozwoju gospodarczego, region, stopień otwartości czy też strukturę przedmiotową eksportu. Jedynie wąska grupa krajów najsłabiej rozwiniętych, o znikomym znaczeniu w gospodarce światowej, odnotowała wzrost obrotów handlowych. Wśród czołowych eksporterów największego spadku wartości eksportu w roku 2009 doświadczyły Japonia (-25,7\%) i Niemcy 
(-22,6\%). Nieco mniejsze załamanie dotyczyło eksportu Stanów Zjednoczonych i Chin.

Tabela 1. Tempo wzrostu wartości eksportu towarów w latach 2008-2015 (zmiana $\mathrm{w}$ stosunku do roku poprzedniego w \%)

\begin{tabular}{|l|r|r|r|r|r|r|r|r|}
\hline \multicolumn{1}{|c|}{ Kraj/region } & 2008 & 2009 & 2010 & 2011 & 2012 & 2013 & 2014 & 2015 \\
\hline Świat & 15,2 & $-22,2$ & 21,9 & 19,8 & 0,9 & 2,4 & 0,3 & $-12,9$ \\
\hline Kraje rozwijające się & 18,9 & $-20,6$ & 28,6 & 22,7 & 4,2 & 2,4 & 0,6 & $-12,6$ \\
\hline Kraje rozwinięte gospodarczo & 11,5 & $-22,4$ & 16,5 & 16,6 & $-1,9$ & 2,8 & 0,5 & $-11,7$ \\
\hline Chiny & 17,2 & $-16,0$ & 31,3 & 20,3 & 7,9 & 7,8 & 6,0 & $-2,9$ \\
\hline Niemcy & 9,5 & $-22,6$ & 12,4 & 17,1 & $-4,9$ & 3,1 & 3,4 & $-11,0$ \\
\hline Japonia & 9,4 & $-25,7$ & 32,6 & 6,9 & $-3,0$ & $-10,5$ & $-3,5$ & $-9,5$ \\
\hline Stany Zjednoczone & 12,1 & $-18,0$ & 21,1 & 16,0 & 4,3 & 2,2 & 2,6 & $-7,1$ \\
\hline
\end{tabular}

Źródło: [UNCTAD, 2017].

Od II kwartału 2009 r. do III kwartału 2011 r. wartość eksportu systematycznie rosła, a w II kwartale 2011 r. osiągnęła poziom z III kwartału 2008 r. Niestety już w IV kwartale 2011 r. dynamika wzrostu handlu światowego spadła, a niskie tempo wzrostu utrzymywało się do III kwartału 2014 r. W IV kwartale rozpoczął się spadek obrotów w handlu międzynarodowym, spowodowany przede wszystkim spadkiem cen. Wolumen obrotów handlowych w latach 2013-2015 rósł w tempie 2,6\%, wartość jednostkowa spadła jednak o 6\%, co w konsekwencji spowodowało obniżenie wartości handlu światowego o 3,6\% [WTO, 2016, s. 22].

Tempo wzrostu wartości eksportu w latach 2008-2015 było zróżnicowane w zależności od grupy towarowej (tab. 2). Największe spadki w roku 2009 dotyczyły paliw mineralnych $(-37,2 \%)$, podstawowych artykułów przemysłowych sklasyfikowanych według materiałów $(-28,2 \%)$, olejów i tłuszczy $(-27,3 \%)$ oraz surowców innych niż paliwa mineralne $(-24,7 \%)$. Były to zatem produkty o relatywnie niewielkim stopniu przetworzenia, oparte na surowcach mineralnych i surowcach rolnych. Również w latach 2010-2015 tempo wzrostu wartości eksportu produktów należących do wymienionych grup było najniższe, a w roku 2015 spadki wartości były największe.

Wskutek załamania handlu międzynarodowego nastąpił spadek udziału światowego eksportu towarów i usług w globalnym PKB (rys. 1). W roku 2008 udział ten wynosił 30,8\% i spadł do $26,6 \%$ w roku 2009. Po okresie relatywnie szybkiego wzrostu w latach 2010-2011 od roku 2012 ponownie pojawiła się tendencja spadkowa, która jest wynikiem niższej od wzrostu PKB dynamiki handlu międzynarodowego. Spadek ten różni się od historycznych doświadczeń z lat 1990-1993 oraz 2001-2002. O ile podczas poprzednich recesji zmniejszenie udziału eksportu 
w PKB miało charakter krótkotrwały (1-2 lata), o tyle obecnie spadkowa tendencja utrzymuje się znacznie dłużej, a dostępne prognozy sugerują podtrzymanie trendu.

Tabela 2. Wzrost wartości światowego eksportu towarowego w latach 2008-2015 (zmiana $\mathrm{w}$ stosunku do roku poprzedniego $\mathrm{w} \%$ )

\begin{tabular}{|l|r|r|r|r|r|r|r|r|}
\hline \multicolumn{1}{|c|}{ Grupa towarów } & 2008 & 2009 & 2010 & 2011 & 2012 & 2013 & 2014 & 2015 \\
\hline Żywność i żywe zwierzęta & 20,0 & $-8,9$ & 12,2 & 20,6 & 0,2 & 6,8 & 3,9 & $-9,4$ \\
\hline Tytoń i napoje & 9,5 & $-6,5$ & 6,3 & 16,3 & 3,4 & 5,3 & 0,1 & $-6,0$ \\
\hline Surowce inne niż paliwa mineralne & 15,5 & $-24,7$ & 44,0 & 27,0 & $-6,8$ & 0,9 & $-3,9$ & $-18,9$ \\
\hline Paliwa mineralne & 41,6 & $-37,2$ & 31,1 & 38,7 & 3,9 & $-1,5$ & $-6,6$ & $-39,0$ \\
\hline Oleje i tłuszcze & 46,1 & $-27,3$ & 24,5 & 37,6 & $-3,7$ & $-7,4$ & $-1,6$ & $-11,7$ \\
\hline Chemikalia & 14,3 & $-14,5$ & 17,9 & 17,1 & $-1,7$ & 3,1 & 1,8 & $-8,8$ \\
\hline $\begin{array}{l}\text { Podstawowe artykuły } \\
\text { przemysłowe wg materiałów }\end{array}$ & 9,7 & $-28,2$ & 24,7 & 20,5 & $-5,1$ & 2,0 & 2,1 & $-11,2$ \\
\hline $\begin{array}{l}\text { Maszyny, urządzenia } \\
\text { i środki transportu }\end{array}$ & 7,3 & $-22,4$ & 22,1 & 13,3 & 0,8 & 3,5 & 3,1 & $-4,6$ \\
\hline Inne wyroby przemysłowe & 8,7 & $-12,7$ & 14,8 & 16,0 & 4,1 & 4,9 & 5,2 & $-4,8$ \\
\hline $\begin{array}{l}\text { Inne wyroby nie wymienione } \\
\text { wcześniej }\end{array}$ & 22,2 & $-1,4$ & 10,7 & 16,8 & 10,5 & 9,4 & $-17,9$ & $-4,9$ \\
\hline
\end{tabular}

Źródło: [UNCTAD, 2017].

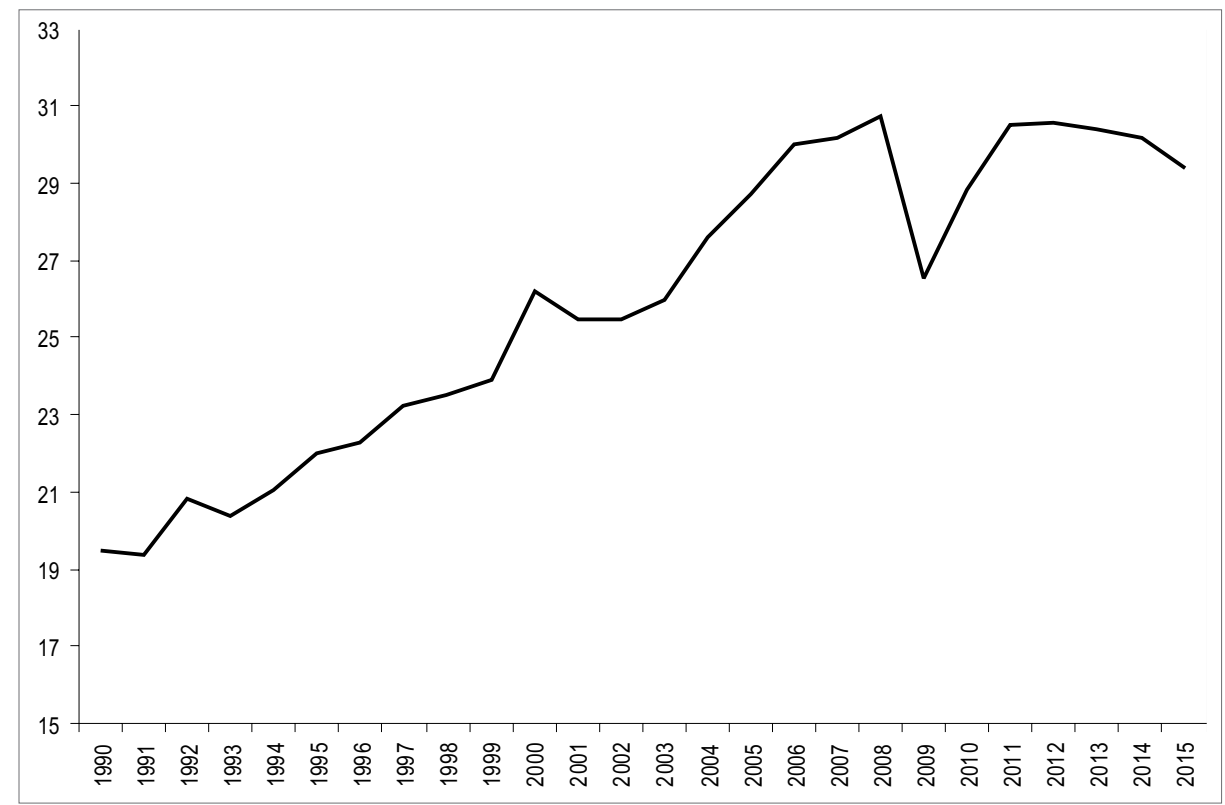

Rysunek 1. Udział światowego eksportu towarów i usług w globalnym PKB w latach 1990-2015 (w \%)

Źródło: [World Bank, 2017b]. 


\section{Czynniki załamania handlu międzynarodowego w roku 2009}

Wśród ekonomistów zajmujących się problematyką handlu międzynarodowego istnieje relatywnie wysoka zgodność poglądów co do przyczyn załamania wymiany w roku 2009. Najczęściej wymieniane są cztery czynniki [WTO, 2009, s. 2]:

- powszechny spadek popytu, który był większy niż we wcześniejszych kryzysach i dotyczył wszystkich regionów świata;

- wysoki stopień fragmentacji procesów produkcyjnych pomiędzy krajami, sprawiający, że dekoniunktura szybko rozprzestrzeniała się na kolejne rynki;

- niewystarczająca podaż środków potrzebnych do sfinansowania transakcji handlowych spowodowana kryzysem finansowym;

- narastające tendencje protekcjonistyczne, które utrudniały rozwój wymiany.

Podstawowym czynnikiem załamania handlu w roku 2009 był globalny spadek popytu. Potwierdziły to liczne analizy, w których znaczenie czynników popytowych oszacowano na 40-75\% całkowitego spadku wartości handlu. Szczególnie istotny był spadek popytu inwestycyjnego [por. Levchenko, Lewis, Tesar, 2010; Bems, Johnson, Yi, 2013]. Efekt ten został wzmocniony przez postępującą fragmentację procesów produkcji i rozwój wymiany podzespołami i dobrami pośrednimi. Spowodował on wyraźny wzrost dochodowej elastyczności eksportu i przyspieszył rozprzestrzenianie się dekoniunktury w gospodarce światowej.

Kryzys finansowy lat 2008-2009 wywołał problemy z realizacją płatności handlu zagranicznego, ale również pozwolił na lepsze poznanie roli sprawnego finansowania transakcji. Dostępne analizy wskazują, że wiele banków pośredniczących $\mathrm{w}$ transakcjach wstrzymało lub istotnie zmniejszyło krótkoterminowe finansowanie [por. Asmundson i in., 2011; Korinek, Le Cocguic, Sourdin, 2010]. Istotnym czynnikiem ograniczenia finansowania transakcji handlowych było rosnące ryzyko niewypłacalności. Mary Amiti i David Weinstein [2011] wykazali związek pomiędzy czasem transportu, ryzykiem płatności i wartością handlu. Wartość eksportu była niższa, gdy czas transportu, a tym samym czas oczekiwania na płatności był długi.

Podobnie jak w przypadku wcześniejszych okresów dekoniunktury, w latach 2008-2009 nastąpiły zmiany w polityce handlowej. Polegały one głównie na wzroście protekcjonizmu, który w większości przypadków dotyczył wprowadzenia nowych barier o charakterze pozataryfowym i regulacyjnym. Wzrost ceł dotknął jedynie ograniczoną liczbę krajów, a większość kontynuowała proces liberalizacji ceł. Zgodnie z danymi podawanymi przez Mohini Datt, Bernarda Hoekmana i Mariem Malouche [2011, s. 4] od września 2008 r. do października 2011 r. zarówno w krajach grupy G-20, jak i w słabiej rozwiniętych gospodarkach zanotowano więcej przypadków obniżek ceł niż ich podnoszenia. Niemniej jednak wprowadzono liczne ograniczenia o charakterze pozataryfowym oraz mniej przejrzyste wewnętrzne przepisy regulacyjne i różnorodne formy wsparcia krajowych pro- 
ducentów. Analizy przeprowadzone przez Simona J. Evenetta [2010], Kishore Gawande, Bernarda Hoekmana, Yue Cui [2011] oraz Christiana Henna i Brada McDonalda [2011] jednoznacznie wskazują na istotny wzrost protekcjonizmu. Od listopada 2008 do końca 2010 r. udokumentowano około 1400 przypadków wprowadzenia nowych ograniczeń w handlu. Pomimo wzrostu protekcjonizmu nie wywarł on istotnego wpływu na spadek handlu międzynarodowego.

\section{Czynniki stagnacji handlu międzynarodowego w latach 2012-2015}

Jednym z najczęściej przytaczanych powodów spowolnienia handlu międzynarodowego po roku 2012 jest zjawisko sekularnej stagnacji, oznaczające trwałe zahamowanie wzrostu gospodarczego w krajach rozwiniętych gospodarczo. Po raz pierwszy terminu tego użył Alvin H. Hansen 28 grudnia 1938 r. podczas wystąpienia w trakcie 51. spotkania Amerykańskiego Towarzystwa Ekonomicznego w Detroit, opublikowanego następnie na łamach „American Economic Review”. Zjawisko sekularnej stagnacji łłumaczył on spadkiem dzietności i starzeniem się społeczeństwa, co prowadziło do osłabienia popytu, a tym samym obniżenia skłonności do inwestowania [Hansen, 1939, s. 4]. Koncepcję Hansena odświeżył Lawrence Summers w kontekście spowolnienia gospodarczego, którego doświadczyły gospodarki wysoko rozwinięte po kryzysie lat 2008-2009 [Summers, 2014]. Tak zwana nowa sekularna stagnacja może być użyteczna również do wyjaśnienia spowolnienia handlu. Summers argumentuje, że zbyt wysokie oszczędności i zbyt niskie inwestycje są przeszkodą dla wzrostu gospodarczego krajów wysoko rozwiniętych [Summers, 2016]. Ponieważ związek pomiędzy inwestycjami a handlem jest bardzo silny, spowolnienie obrotów staje się wyraźnie odczuwalne. Mechanizm łączący inwestycje $z$ handlem jest prosty. Spadające inwestycje powodują zmniejszenie popytu importowego w krajach wysoko rozwiniętych, co przekłada się również na malejący eksport producentów maszyn, urządzeń i dóbr pośrednich [Freund, 2016].

Prosta analiza danych statystycznych pokazujących udział inwestycji w PKB krajów wysoko rozwiniętych gospodarczo potwierdza wyraźne załamanie aktywności inwestycyjnej (rys. 2). Proces ten rozpoczął się w roku 2007 w Stanach Zjednoczonych, a z rocznym opóźnieniem w strefie euro i pozostałych krajach wysoko rozwiniętych. Stopa inwestycji w USA spadła z 23,3\% w roku 2006 do 17,5\% w roku 2009, a następnie rozpoczął się trwający aż do roku 2015 wzrost. Stopa inwestycji z roku 2006 nie została jednak ponownie osiągnięta. W strefie euro spadek inwestycji w latach 2008-2009 przebiegał podobnie jak w USA, niemniej wzrostowa tendencja dotyczyła jedynie lat 2010-2011. W latach 2012-2013 nastąpił spadek stopy inwestycji, a od roku 2014 można odnotować ich stabilizację na niskim poziomie, nieprzekraczającym 20\% PKB. 
Teza o istotnym wpływie nowej sekularnej stagnacji na spowolnienie handlu międzynarodowego znajduje potwierdzenie w badaniach ekonometrycznych. Eksperci Międzynarodowego Funduszu Walutowego wskazują, że niską dynamikę wzrostu realnego importu towarowego w latach 2012-2015 w około 75\% można wyjaśnić słabą aktywnością gospodarczą, a zwłaszcza spadkiem inwestycji [IMF, 2016a, s. 65]. Potwierdzają to również wcześniejsze badania przeprowadzone przez Matthieu Bussierego, Giovanniego Callegariego, Fabio Ghironiego, Giulie Sestieri i Norihiko Yamano [2013]. Wykazali oni, że załamanie popytu inwestycyjnego oraz eksportu (popytu zewnętrznego) w dużej mierze wyjaśnia spowolnienie obrotów w handlu międzynarodowym.

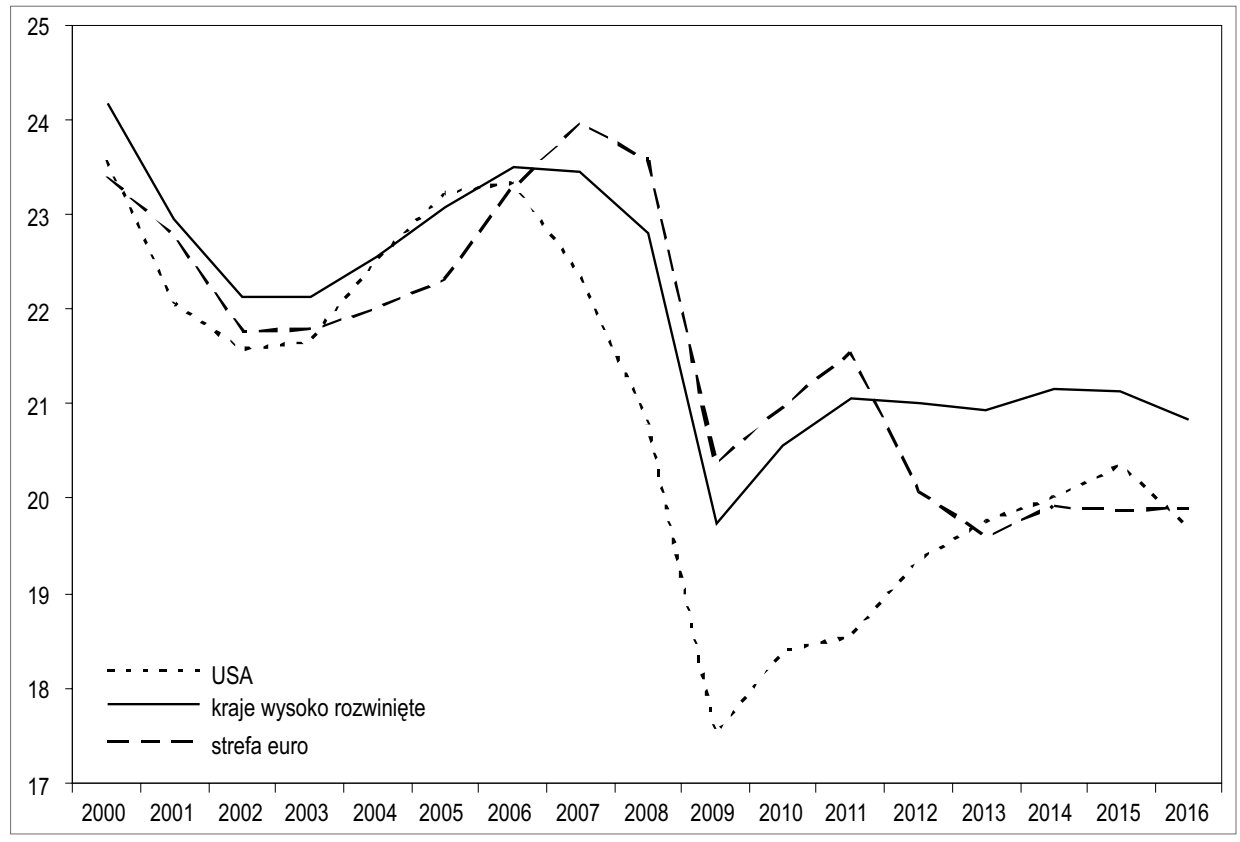

Rysunek 2. Udział inwestycji w PKB krajów wysoko rozwiniętych w latach 2000-2016 (w \%) Źródło: [IMF, 2016b].

Drugim analizowanym czynnikiem jest spadek dochodowej elastyczności handlu. Kryzys gospodarczy lat 2008-2009 nie tylko spowodował obniżenie dynamiki PKB i wymiany handlowej, ale również zmienił charakter wzajemnych zależności zachodzących pomiędzy tymi zmiennymi. Cristina Constantinescu, Aaditya Mattoo i Michele Ruta wykazali, że w latach 2001-2007 1-procentowy wzrost dochodu powodował wzrost handlu o 1,5\%, natomiast w latach 2008-2013 już tylko o 0,7\% [Constantinescu, Mattoo, Ruta, 2015, s. 5]. Jednym z najważniejszych czynników spadku dochodowej elastyczności handlu było osłabienie globalnych 
powiązań produkcyjnych. Jak wskazywano wcześniej, geograficzna fragmentacja procesów produkcji, pogłębiająca się od lat dziewięćdziesiątych XX w., była jednym z głównych powodów załamania handlu w roku 2009. Czy rzeczywiście po roku 2009 mamy do czynienia ze zjawiskiem, które można określić mianem refragmentacji produkcji, a zatem z jej ponowną koncentracją w jednej lokalizacji?

Podstawowym problemem badawczym $\mathrm{w}$ ocenie zjawiska fragmentacji produkcji jest dobranie właściwych mierników. Jednym z najczęściej stosowanych wskaźników jest udział zagranicznej wartości dodanej w eksporcie brutto. Eksport brutto to suma krajowej bezpośredniej i pośredniej wartości dodanej, którą dany kraj eksportuje do innych krajów, oraz zagranicznej wartości dodanej, na którą składają się wcześniej importowane zagraniczne komponenty, podzespoły i surowce wykorzystywane $\mathrm{w}$ procesie produkcji. Istnieją trzy podstawowe źródła danych o udziale zagranicznej wartości dodanej w eksporcie brutto. Pierwszym z nich jest baza TiVA, będąca wspólną inicjatywą WTO i OECD, drugą baza WIOD, tworzona przez konsorcjum uniwersytetów i instytutów badawczych z Europy. Ostatni projekt, EORA, powstał z inicjatywy UNCTAD. Trzecia baza, wykorzystana w niniejszym opracowaniu, obejmuje największą liczbę gospodarek i najszerszy horyzont czasowy ${ }^{1}$.

Opierając się na obliczeniach wykonanych na podstawie danych zawartych w bazie EORA, możemy stwierdzić, że od początku lat dziewięćdziesiątych XX w. aż do roku 2008 udział zagranicznej wartości dodanej w światowym eksporcie brutto charakteryzował się wyraźną tendencją wzrostową (rys. 3). W latach 1990-2008 udział zagranicznych komponentów i podzespołów w światowym eksporcie wzrósł z 23,6\% do 31,0\%. W roku 2009 nastąpił spadek o 2 p.p., a od roku 2010 wskaźnik ustabilizował się na poziomie około $30 \%$.

Podobne wyniki uzyskali, opierając się na bazie WIOD, Marcel Timmer, Bart Los, Robert Stehrer oraz Gaaitzen J. de Vries [2016]. Zaproponowali oni nową metodę mierzenia fragmentacji produkcji, a zastosowany wskaźnik nazwali Global Import Intensity (GII). Mierzy on import podzespołów, surowców i części potrzebnych na wszystkich stadiach procesu produkcji. Wskaźnik GII rósł w latach 2000-2008, osiągając w 2008 r. 33\%. W roku 2009 nastąpił jego spadek o około 5 p.p., a od roku 2011 ustabilizował się on na poziomie około 30\%, tendencja jest jednak spadkowa [Timmer i in., 2016, s. 5]. Jak wskazują Timmer i inni, gdy GII maleje, elastyczność dochodowa importu jest mniejsza od 1.

1 Baza WIOD (2016) zawiera dane dla 43 krajów i zagregowane dla reszty świata obejmujące lata 2000-2014. Wcześniejsza wersja bazy (2013) zawiera dane dla 40 gospodarek i reszty świata i obejmuje lata 1995-2011. Różna metodologia powoduje jednak, że dane nie są w pełni porównywalne. Baza TIVA zawiera dane dla 61 gospodarek i reszty świata i obejmuje lata 1995-2011. Baza EORA zawiera dane dla 189 gospodarek i obejmuje lata 1990-2012. 


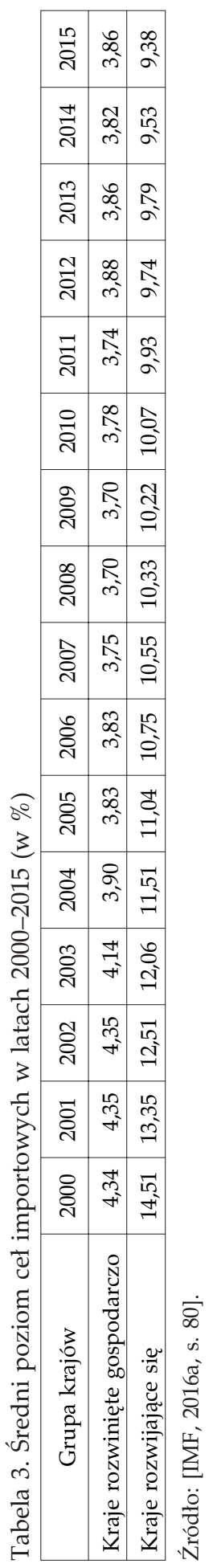




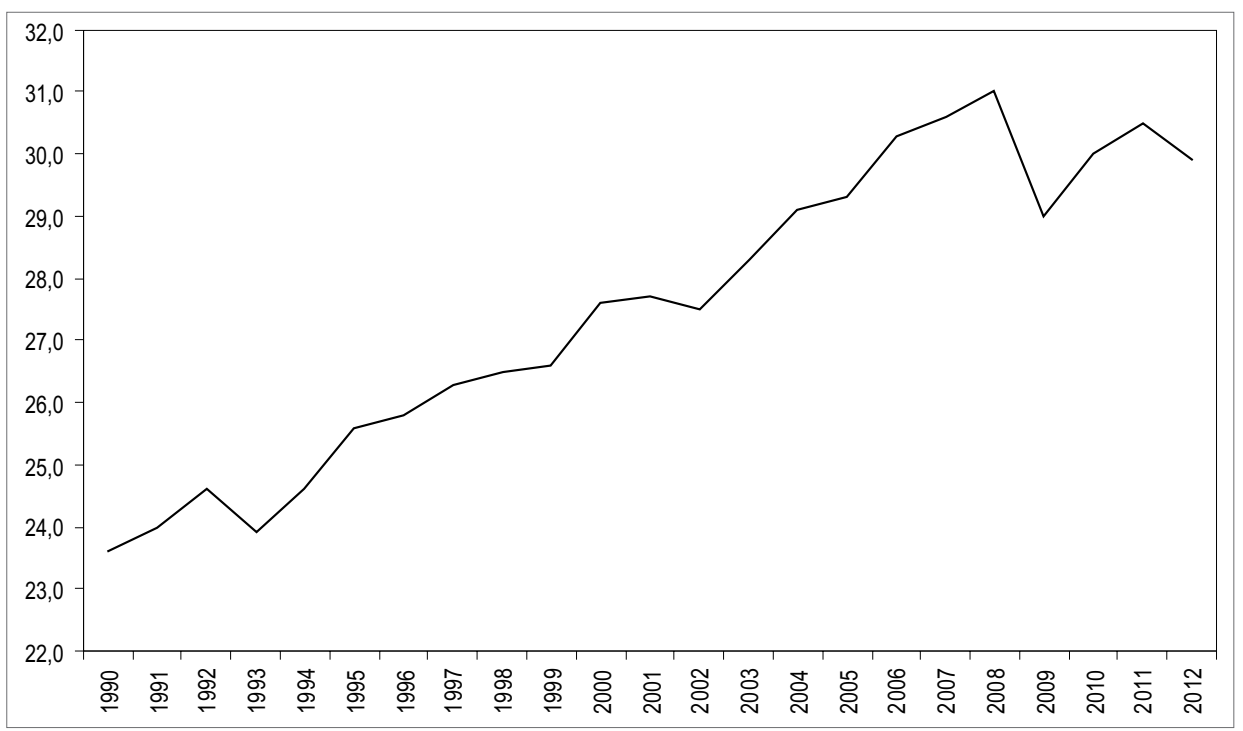

Rysunek 3. Udział zagranicznej wartości dodanej w światowym eksporcie w latach 1990-2012 (w \%)

Źródło: [EORA, 2017].

Trzecim czynnikiem stagnacji $\mathrm{w}$ handlu międzynarodowym jest brak postępów w liberalizacji oraz wzrost protekcjonizmu pozataryfowego, zwłaszcza barier regulacyjnych. Spowolnieniu uległy również procesy regionalizacji handlu. Zgodnie z danymi podawanymi przez autorów raportu IMF [2016a] średni poziom ceł w krajach rozwiniętych gospodarczo w latach 2000-2007 spadł z 4,34\% do 3,75\% , a w gospodarkach rozwijających się z $14,51 \%$ do 10,55\% (tab. 3). Po roku 2008 proces liberalizacji w grupie krajów rozwijających się wyraźnie zwolnił. W latach 2008-2015 cła spadły o około 1 p.p. do 9,38\% w roku 2015. Natomiast w grupie krajów rozwiniętych gospodarczo cła minimalnie wzrosły. W roku 2015 średni poziom ceł w tej grupie wynosił 3,86\%.

Istotny wpływ na spowolnienie handlu miało również nasilenie protekcjonizmu pozataryfowego. Wzrost liczby postępowań antydumpingowych oraz wprowadzanych tymczasowych barier ochronnych odnotowano już w latach 2008-2010, jednak dopiero w latach 2013-2015 nastąpiło wyraźne nasilenie stosowania tych instrumentów polityki handlowej. Na podstawie danych Banku Światowego zgromadzonych w bazie Temporary Trade Barriers możemy określić odsetek produktów objętych ograniczeniami. Największy wzrost protekcjonizmu dotyczył postępowań antydumpingowych. W latach 2008-2010 udział objętych nimi produktów wzrósł z 1,7\% do 1,9\%. Po roku 2013 liczba przeprowadzonych postępowań istotnie wzrosła, a w roku 2015 objęto nimi już 2,3\% produktów. Mniej istotne były wprowadzane cła wyrównawcze i postępowania ochronne. Objęto 
nimi niewielką część handlu, a liczba produktów, których dotyczyły, nie przekraczała w całym okresie $0,5 \%$.

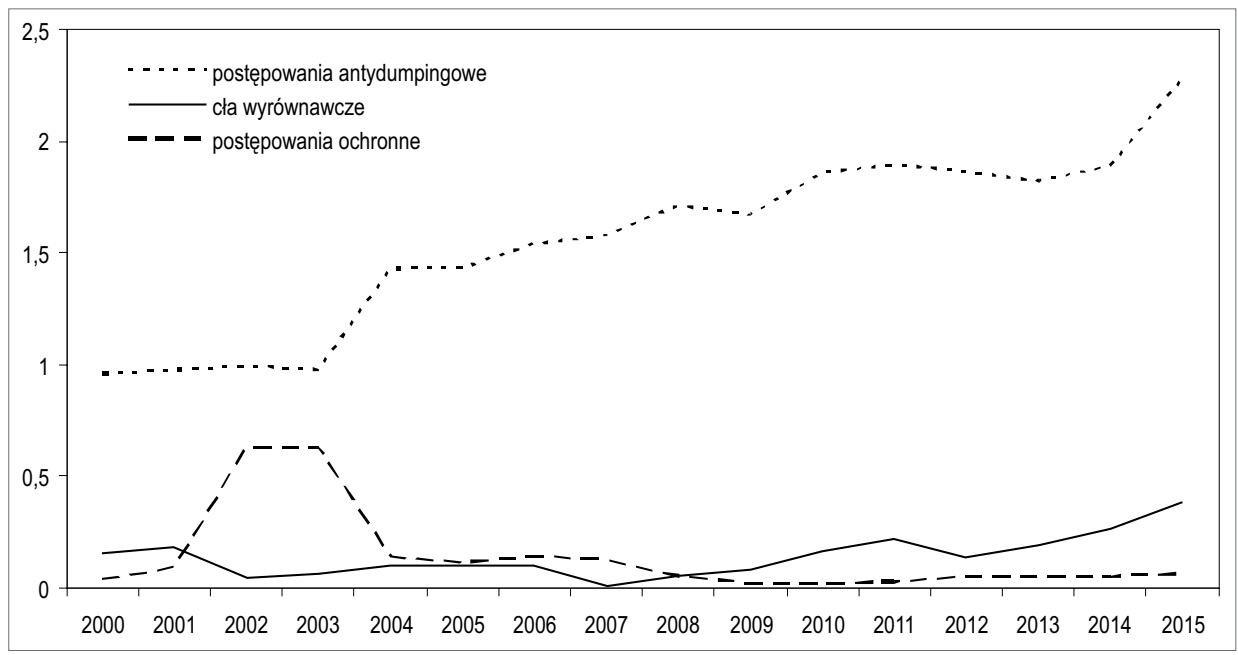

Rysunek 4. Udział produktów objętych tymczasowymi barierami ochronnymi w latach 2000-2015 (w \%)

Źródło: [World Bank, 2017a].

Drugim źródłem danych zawierającym informacje o zakresie stosowanych barier pozataryfowych jest baza Global Trade Alert utworzona z inicjatywy Centre for Economic Policy Research. Na jej podstawie jesteśmy w stanie określić liczbę wprowadzanych i eliminowanych barier. W latach 2012-2015 nowymi ograniczeniami dyskryminującymi objęto łącznie 21768 produktów, natomiast skala liberalizacji była dwukrotnie mniejsza i dotyczyła 10722 produktów (tab. 4). Najwięcej ograniczeń wprowadzono w latach 2014-2015. Warto jednak podkreślić istotny postęp w liberalizacji, który nastąpił w roku 2015. Zniesiono wówczas ograniczenia na 5297 produktów.

Tabela 4. Liczba produktów objętych ograniczeniami pozataryfowymi w latach 2009-2015

\begin{tabular}{|c|c|c|}
\hline Rok & Liberalizujące & Dyskryminujące \\
\hline 2009 & 2294 & -3847 \\
\hline 2010 & 2146 & -4381 \\
\hline 2011 & 840 & -2009 \\
\hline 2012 & 1613 & -2768 \\
\hline 2013 & 1966 & -3564 \\
\hline 2014 & 1846 & -6907 \\
\hline 2015 & 5297 & -8529 \\
\hline
\end{tabular}

Źródło: [Global Trade Alert, 2017]. 
Brak postępów w multilateralnej liberalizacji handlu międzynarodowego na forum Światowej Organizacji Handlu i przedłużające się rozmowy w ramach Rundy Doha przyczyniły się do wzrostu liczby podpisywanych układów regionalnych o preferencyjnej współpracy handlowej [por. Mucha-Leszko, 2014; Wojtas, 2016]. Jednak po roku 2008 znaczenie tej formy liberalizacji handlu zmalało. Zgodnie z danymi WTO w latach 2000-2007 podpisywano średniorocznie 26 nowych porozumień regionalnych, w latach 2008-2011 ich liczba spadła do 17 rocznie, a w latach 2012-2015 do 10.

Ostatnim analizowanym czynnikiem jest spadek cen eksportowych. Na istotny wpływ tendencji deflacyjnych na wartość i dynamikę światowego handlu wskazują ogólne statystyki podawane przez ekspertów Światowej Organizacji Handlu. Wartość światowego handlu w latach 2006-2010 rosła średniorocznie o 9,0\%, a wzrost ten był spowodowany zarówno wzrostem wolumenu obrotów, jak i wartości jednostkowej produktów. W latach 2013-2015 wzrost wartości był ujemny $(-3,6 \%)$, jednak w ujęciu wolumenowym osiągnięto dodatni wzrost na poziomie $2,6 \%$, a spadek wartości był spowodowany wyłącznie ujemnym wzrostem wartości jednostkowej (-6,0\%) [WTO, 2016, s. 22].

Szczegółowe statystyki pokazujące tendencje zachodzące w kształtowaniu się cen eksportowych w latach 2008-2015 potwierdzają istotny wpływ deflacji. Szczególnie wyraźne spadki cen eksportowych wystąpiły w roku 2009 oraz w latach 2012-2015 (tab. 5). Największe spadki cen dotyczyły surowców energetycznych, a zwłaszcza ropy naftowej. Były one spowodowane obniżeniem popytu na surowce energetyczne, wywołanym w pierwszej kolejności ogólnoświatowym kryzysem gospodarczym (2009), spowolnieniem w Europie i w Chinach (2012-2015), a także wzrostem podaży w związku z rosnącym wydobyciem w Ameryce Północnej i zwiększoną produkcją ropy łupkowej [AIECE, 2015, s. 12-13]. W rezultacie wartość światowego eksportu ropy naftowej spadła w latach 2014-2015 z 2535 mld USD do 1480 mld USD [UNCTAD, 2017].

Tabela 5. Ceny eksportowe wybranych grup towarów podstawowych w latach 2008-2015 $(2008=100)$

\begin{tabular}{|l|c|c|c|c|c|c|c|c|}
\hline \multicolumn{1}{|c|}{ Grupa towarów } & 2008 & 2009 & 2010 & 2011 & 2012 & 2013 & 2014 & 2015 \\
\hline Żywność i napoje & 100 & 87 & 98 & 117 & 112 & 112 & 109 & 92 \\
\hline Surowce rolne & 100 & 83 & 110 & 135 & 118 & 120 & 123 & 106 \\
\hline Minerały i metale nieżelazne & 100 & 81 & 119 & 136 & 113 & 108 & 97 & 75 \\
\hline Surowce energetyczne & 100 & 63 & 80 & 109 & 110 & 106 & 97 & 54 \\
\hline Ropa naftowa & 100 & 64 & 82 & 112 & 114 & 111 & 101 & 53 \\
\hline
\end{tabular}

Źródło: [WTO, 2016, s. 161]. 


\section{Podsumowanie}

Analiza głównych czynników załamania handlu międzynarodowego w roku 2009 i jego stagnacji w latach 2012-2015 pozwala na sformułowanie kilku wniosków. Po pierwsze, zarówno w roku 2009, jak i w latach 2012-2015 głównym czynnikiem spadku obrotów handlowych było załamanie popytu, w szczególności inwestycyjnego. W pierwszym okresie było ono spowodowane kryzysem finansowo-gospodarczym, w drugim wiązało się ze zjawiskiem sekularnej stagnacji.

Po drugie, ważnym czynnikiem wpływającym na rozwój handlu są zmiany dochodowej elastyczności eksportu spowodowane procesem międzynarodowej fragmentacji produkcji. Pionowa specjalizacja w handlu pogłębiała się od lat dziewięćdziesiątych XX w. aż do roku 2008. W rezultacie nastąpił wzrost dochodowej elastyczności eksportu. Od roku 2009 powiązania produkcyjne osłabły, a elastyczność spadła poniżej 1.

Po trzecie, kryzys gospodarczy przyczynił się do nasilenia tendencji protekcjonistycznych, zwłaszcza o charakterze pozataryfowym. Nie miały one jednak dużego wpływu na rozwój handlu międzynarodowego.

Specyficznymi czynnikami dla roku 2009 i lat 2012-2015 były odpowiednio problemy z finansowaniem transakcji handlowych oraz spadek cen eksportowych. W obu przypadkach istotnie przyczyniły się one do spadku wartości wymiany handlowej.

Bibliografia

AIECE, 2015, World Trade and Commodity Prices in 2015-2016.

Amiti M., Weinstein D., 2011, Exports and Financial Shocks, Quarterly Journal of Economics, vol. 126, no. 4.

Asmundson I., Dorsey T., Khachatryan A., Niculcea I., Saito M., 2011, Trade Finance in the 2008-2009 Financial Crisis. Evidence from IMF and BAFT-IFSA Surveys of Banks, [w:] Trade Finance during the Great Trade Collapse, ed. J-P. Chauffour, M. Malouche, The World Bank, Washington.

Bems R., Johnson R.C., Yi K-M., 2013, The Great Trade Collapse, Annual Review of Economics, vol. 5 , no. 1 .

Bussiere M., Callegari G., Ghironi F., Sestieri G., Yamano N., 2013, Estimating Trade Elasticities. Demand Composition and the Trade Collapse of 2008-2009, American Economic Journal: Macroeconomics, vol. 5, no. 3.

Constantinescu C., Mattoo A., Ruta M., 2015, The Global Trade Slowdown. Cyclical or Structural?, IMF Working Paper, no. 15/06.

Datt M., Hoekman B., Malouche M., 2011, Taking Stock of Trade Protectionism Since 2008, World Bank Economic Premise, no. 72.

EORA, 2017, Multi-region input-output table, http://www.worldmrio.com/[dostęp: 15.03.2017]. 
Evenett S.J. (ed.), 2011, Tensions Contained... For Now: The 8th GTA Report, Centre for Economic Policy Research, London.

Freund C., 2016, The Global Trade Slowdown and Secular Stagnation, https://piie.com/blogs/ trade-investment-policy-watch/global-trade-slowdown-and-secular-stagnation [dostęp: 15.03.2017].

Gawande K., Hoekman B., Cui Y., 2011, Determinants of Trade Policy Responses to the 2008 Financial Crisis, World Bank Policy Research Working Paper, no. 5862.

Global Trade Alert, 2017, http://www.globaltradealert.org/data-exports [dostęp: 15.03.2017].

Hansen A.H., 1939, Economic Progress and Declining Population Growth, American Economic Review, vol. 29, no. 1, Part I.

Henn Ch., McDonald B., 2011, Protectionist Responses to the Crisis. Damage Observed in Product-Level Trade, IMF Working Paper, no. 139.

IMF, 2016a, World Economic Outlook: Subdued Demand - Symptoms and Remedies.

IMF, 2016b, World Economic Outlook Database, October 2016, http://www.imf.org/external/ pubs/ft/weo/2016/02/weodata/index.aspx [dostęp: 15.03.2017].

Korinek J., Le Cocguic J., Sourdin P., 2010, The Availability and Cost of Short-Term Trade Finance and its Impact on Trade, OECD Trade Policy Working Paper, no. 98.

Levchenko A.A., Lewis L.T., Tesar L.L., 2010, The Collapse of International Trade during the 2008-2009 Crisis. In Search of the Smoking Gun, IMF Economic Review, vol. 58, no. 2.

Mucha-Leszko B., 2014, Globalna czy regionalna liberalizacja handlu międzynarodowego?, Zeszyty Naukowe Uniwersytetu Szczecińskiego. Współczesne Problemy Ekonomiczne. Globalizacja. Liberalizacja. Etyka, nr 8.

Summers L.H., 2014, Reflections on the "New Secular Stagnation Hypothesis" [w:] Secular Stagnation. Facts, Causes, and Cures, ed. C. Teulings, R. Baldwin, CEPR Press, London.

Summers L.H., 2016, The Age of Secular Stagnation. What It Is and What to Do About It, Foreign Affairs, https://www.foreignaffairs.com/articles/united-states/2016-02-15/age-secularstagnation [dostęp: 15.03.2017].

Timmer M., Los B., Stehrer R., de Vries G.J., 2016, An Anatomy of the Global Trade Slowdown based on the WIOD 2016 Release, GGDC Research Memorandum, no. 162.

UNCTAD, 2017, UNCTADStat, http:/unctadstat.unctad.org/ [dostęp: 15.03.2017].

Wojtas M., 2016, Negocjacje Rundy Doha - postępy w czasie Konferencji Ministerialnych w Bali i Nairobi, Finanse, Rynki Finansowe, Ubezpieczenia, nr 3.

World Bank, 2017a, Temporary Trade Barriers Database, http://siteresources.worldbank.org/ INTTRADERESEARCH/Resources/544824-1272916036631/TTBD_2016.zip [dostęp: 15.03.2017].

World Bank, 2017b, World Development Indicators, 23 March, 2017, http://databank.worldbank.org/data/download/WDI_excel.zip [dostęp: 15.03.2017].

WTO, 2009, World Trade Report 2009.

WTO, 2016, World Trade Statistical Review 2016.

WTO, 2017, Quarterly world merchandise export developments since 2005, http://www.wto. org/english/res_e/statis_e/quarterly_world_exp_e.htm [dostęp: 15.03.2017].

T. Białowąs ( ) bialowas@hektor.umcs.lublin.pl

Katedra Gospodarki Światowej i Integracji Europejskiej, Wydział Ekonomiczny, Uniwersytet Marii Curie-Skłodowskiej w Lublinie, pl. Marii Curie-Skłodowskiej 5, 20-031 Lublin, Polska 